\title{
Norske kommuner i elektronisk utakt? Fra sosiale til geografiske digitale ulikheter
}

\author{
Knut H. Sorensen \& Lucía Liste Muñoz
}

Utviklingen innenfor informasjons- og kommunikasjonsteknologi (IKT) har gitt opphav til en type etisk-politisk utfordring som gjerne kalles digital ulikhet. Tradisjonelt har det dreid seg om sosiale ulikheter i tilgangen til IKT på individnivå. Nyere forskning på området er mer opptatt av bruk og dermed av tilbudet av aktiviteter og tjenester gjennom Internett. I denne artikkelen ser vi på hvordan det kan oppstå geografisk digital ulikhet som følge av at norske kommuner tilbyr digitale tjenester - herunder informasjon og ressurser for lokalpolitisk deltakelse - $i$ svert forskjellig omfang. Det betyr at kommunene står overfor etisk-politiske utfordringer knyttet til digital ulikhet som følge av deres strategier for bruk av hjemmesider, og for digital utvikling av kommunen mer generelt. Selv om det er få kommuner som tilbyr saerlig mye når det gjelder lokalpolitisk deltakelse, er ulikhetene i tilbudet av informasjon og digitale tjenester betydelige. I tillegg bidrar velutviklede hjemmesider til å gjøre kommunen mer gjennomsiktig og lettere tilgjengelig, noe vi antar er en fordel for innbyggerne. Analysen er basert på en kvantitativt orientert innholdsanalyse av hjemmesidene til alle norske kommuner og en kvalitativ innholdsanalyse av hjemmesidene til ti norske kommuner.

Nøkkelord: digital ulikhet, etisk-politiske utfordringer, kommuner, hjemmesider, digitale tjenester

English summary: Norwegian local governments electronically out of step? From social to geographical digital divides

The development of information and communication technologies (ICT) has raised a kind of ethical-political challenge usually referred to as a digital divide. Traditionally, this has fomented concerns about social inequalities with respect to individual access to ICT. More recent scholarship argues the need to be more focused on use rather than access; accordingly, also on the

Knut H. Sørensen, Institutt for tverrfaglige kulturstudier, NTNU, knut.sorensen@ hf.ntnu.no

Lucía Liste Muñoz, Institutt for tverrfaglige kulturstudier, NTNU, lucia.m.liste@ntnu.no 
supply of activities and services through internet. In this article, we study how geographical digital divides may appear as a consequence of the fact that Norwegian local governments supply digital services - including information and resources for local political participation - to quite a different extent. This means that local governments face ethical-political challenges related to digital divides as a consequence of their strategies for the development of home pages and for digital development of local government services more generally. Even though only a few local governments offer much with regard to local political participation, the inequalities with respect to the supply of information and digital services are considerable. In addition, apparently, well-developed home pages make the local government more transparent and more accessible. We believe this to be of advantage to local citizens. The analysis is based on a quantitative content analysis of all Norwegian local governments and a qualitative content analysis of the home pages of 10 local governments.

Keywords: e-government, digital divide, ethical-political challenges, local government, home pages, digital services

\section{eKommunal utakt?}

KS - kommunesektorens interesse- og arbeidsgiverorganisasjon - har lansert følgende visjon for det man kaller eKommunen: «Norske kommuner og fylkeskommuner skal være blant de fremste i verden på innbyggerdialog, digitale tjenester og effektiv e-forvaltning» (KS 2008: 6). Dette er i samsvar med ambisiøse nasjonale mål om effektivisering, verdiskapning og demokratisering gjennom økt satsning på informasjons- og kommunikasjonsteknologi (jf. St.meld. nr. 17 (2006-2007)). Utgangspunktet for denne artikkelen er en antakelse om at realiseringen av eKommune-ambisjonene kan være til gagn for innbyggerne i den enkelte kommunen. Dersom resultatet av denne innsatsen varierer vesentlig fra kommune til kommune, kan det derfor skape en type ulikhet i befolkningen som ikke er ønskelig. For å undersøke hva ekommune-satsninger kan føre til av goder for innbyggerne og graden av forskjell mellom kommunenes innsats, har vi valgt å studere kommunale hjemmesider. I hvor stor grad varierer dette tilbudet fra kommune til kommune, og hva betyr en eventuell slik variasjon? Hva slags etiskpolitiske problemer kan ligge i slike variasjoner?

Tidligere forskning gir grunnlag for å anta at eKommune-strategien er blitt realisert ulikt i norske kommuner, i hvert fall når det gjelder å bruke nettet for lokalpolitiske formål (Baldersheim et al. 2008). I utgangspunktet er det derfor rimelig å anta at arbeidet med å realisere eKommune-strategien faktisk bidrar til å skape nye, såkalte digitale ulikheter som er basert på 
hvor man bor. Vi skal i denne artikkelen belyse hvor store disse ulikhetene er med hensyn til hva som tilbys gjennom kommunenes hjemmesider. Hva slags tjenester gjøres tilgjengelige, og i hvilken form? Hvilke konsekvenser kan ulikhetene ha for innbyggerne? I denne sammenhengen skal vi også se på hva slags etisk-politiske utfordringer som oppstår når man har som mål at det skal være lik nytte av digitaliseringen av norske kommuner.

Det er ikke opplagt at forskjeller som oppstår på grunn av ulikheter i det digitale tjenestetilbudet, har stor praktisk betydning. Internasjonale studier av digitalisering av offentlige tjenester og politikk under merkelappen estat (engelsk: e-government) tyder på at digitalisering av offentlige tjenester er kommet forholdsvis kort. West (2004) hevder på bakgrunn av en studie i USA at forventningene om store endringer gjennom innføring av estattiltak ikke er innfridd. Dutton og Eynon (2009) argumenterer for at Storbritannia er i samme situasjon, selv om det er økende bruk av estat-tilbud blant målgruppene for slike tilbud. Mer generelt argumenterer Peristeras et al. (2009) for at på tross av store investeringer i estat-teknologi i mange land er de innførte løsningene ofte ineffektive og har liten effekt. Slike funn antyder at digitale forskjeller mellom norske kommuner ikke spiller noen særlig rolle.

Estat-forskningen har imidlertid ikke vært opptatt av digitale ulikheter. Faglig sett har denne forskningen vært dominert av statsvitenskap og informasjonssystemtilnærminger, med fokus på fem tema: (1) politiske strategier for utvikling av estat, (2) mulighetene for bruk av IKT til økt demokratisk deltakelse, (3) bruk av estat-ordninger, (4) utvikling og evaluering av programmer for estat og (5) personvern (Liste Muñoz 2010). Mange betrakter imidlertid selve forskningsfeltet som umodent og til dels svakt (jf. eksempelvis Heeks \& Bailur 2007; Norris \& Lloyd 2006). Det skyldes blant annet at det er uklart hva forskning på estat-problemstillinger skal innbære. I tillegg er mange studier preget av en problematisk teknologideterministisk argumentasjon, gjerne knyttet til forventninger om at innføring av IKT $i$ seg $s e l v$ vil endre offentlig sektor. Det kan gjøre utviklingen av digitale ulikheter mer til et spørsmål om teknologiutvikling enn en etisk-politisk utfordring.

Blant de studerte temaene er det Internetts potensial for å endre politiske praksiser som har vakt størst interesse. Det finnes for eksempel forestillinger om at en gjennom bruk av IKT kan realisere deltakerdemokratiske visjoner og øke deltakelsen i offentlige politiske debatter. Tidligere studier har imidlertid hatt betydelig sprik i vurderingene av hvor stort dette potensialet er, og hva som det er realistisk å tenke seg kan oppnås (f.eks. Tsagarousianou et al. 1998). Wiklund (2005) fant at i Sverige var IKT-baserte tjenester bare marginale supplement til etablerte institusjoner. I tillegg var tjenestene i første rekke knyttet til forberedende faser i politiske prosesser. Jensen et al. (2007) observerte imidlertid i en studie fra USA at internettmedierte aktiviteter ikke bare skjedde i forlengelsen av etablerte, off-line poli- 
tiske praksiser. Slike aktiviteter fant sted på egne arenaer. Lusoli et al. (2005) oppsummerer nøkternt med at Internetts politiske effekter foreløpig er små, men understreker at de ikke bør undervurderes.

Tidligere norske studier av betydningen av IKT for kommunal politisk praksis har funnet at det først og fremst er ordførere som kommuniserer elektronisk med innbyggerne og organiserte interesser i lokalsamfunnet. Vanlige kommunestyremedlemmer har slik kontakt i vesentlig mindre grad. Politikerne mottar noen, men ikke mange henvendelser fra publikum gjennom e-post og tilsvarende (Hansen \& Vabo 2008). Saglie og Vabo (2009) observerte at Internett ser ut til å forsterke tradisjonelle forskjeller i politisk deltakelse. I tilknytning til våre problemstillinger er det særlig interessant å notere at Saglie og Vabo fant stor forskjell mellom politikere i små og store kommuner når det gjaldt nettbasert politisk kommunikasjon. Det var imidlertid ingen slik forskjell når det gjaldt innbyggerne for øvrig.

Flak et al. (2005) vurderte estat-tilbudet i alle kommunene i Agder-fylkene og fant at disse kommunenes hjemmesider gjennomgående var lite sofistikerte. Det ble forklart med at det er administrasjonen snarere enn politikerne og innbyggerne som engasjerer seg i digitaliseringen av den kommunale virksomheten, og administrasjonens hovedfokus er på intern effektivitet og reduserte kostnader. Haug (2008) argumenterer derimot for at Internett i form av kommunale hjemmesider spiller en stadig viktigere rolle som kanal for politisk kommunikasjon. Han hevder også at forskjellene mellom tilbudet til norske kommuner er avtakende, men hans hovedfokus er på politisk informasjon snarere enn på politisk deltakelse.

I vår studie av estat-ordninger av typen kommunale hjemmesider skal vi forsøke å bidra til en avklaring av hva slags tilbud slike hjemmesider representerer, og hva slags fordeler de kan gi innbyggerne. Vi skal samtidig analysere graden av ulikhet når det gjelder hva kommunene tilbyr av tjenester gjennom sine hjemmesider. Dette skal tjene som utgangspunkt for en vurdering av de etisk-politiske utfordringene som ligger i den norske ekommune-satsningen. Vi skal imidlertid begynne med å drøfte tidligere forskning om digitale ulikheter som et bakteppe for den videre analysen.

\section{Digitale ulikheter og virtuelle kommunale praksiser}

Med unntak av personvernspørsmål har det å skape like adgangsmuligheter vært oppfattet som den viktigste etisk-politiske utfordringen ved utvikling og bruk av IKT (Norris 2001). Det har lenge vært et uttalt ønske om å unngå såkalte digitale ulikheter der noen grupper av befolkningen er deltakere $\mathrm{i}$ det såkalte informasjonssamfunnet, mens andre blir stående utenfor. I denne sammenhengen har det særlig blitt fokusert på tilgang til teknologier som personlige datamaskiner og Internett (van Dijk \& Hacker 2003; Selwyn 
2004). Adgang til å bruke slike teknologier regnes som kritisk for å få «medlemskap» i informasjonssamfunnet og for å være en velfungerende borger i det 21. århundre.

Den siste stortingsmeldingen som tar for seg IKT-feltet, ble kalt «Eit informasjonssamfunn for alle» (St.meld. nr. 17 (2006-2007)). Denne tittelen kan tyde på at det ble lagt stor vekt på å unngå digitale ulikheter i befolkningen, men faktisk gir meldingen slike ulikheter forholdsvis liten oppmerksomhet. I stedet slår stortingsmeldingen fast at «[n]ordmenn generelt har solid bruk av IKT», og at det i første rekke er folk over 60 år som skiller seg ut med klart mindre IKT-aktivitet enn resten. ${ }^{1}$ Det sentrale målet for norsk IKT-politikk ble presentert som å være å endre det norske samfunnet gjennom økt og mer avansert bruk av IKT på mange områder, innenfor næringsliv så vel som offentlig forvaltning. Ikke minst var det viktig at statlige og kommunale myndigheter gjennom digitalisering skulle endre og effektivisere sine arbeidsprosesser. Dermed skulle det offentlige produsere flere og bedre digitale tjenester, både for allmennheten og næringslivet. Heller ikke i Stortingets behandling av meldingen ble det lagt særlig vekt på mulige problemer som følge av digitale forskjeller i befolkningen, bortsett fra en bekymring om at ikke alle deler av landet hadde like god tilgang på bredbånd. ${ }^{2}$ At kommunene kunne skape en ny type digitale ulikheter ved å velge forskjellig kvalitet på sine tilbud av digitale tjenester, ble ikke nevnt, verken i meldingen eller i Stortingets behandling.

De digitale ulikhetene i Norge, som i andre land, har vært betydelige (se eksempelvis Frønes 2002). Stortingsmeldingen la imidlertid vekt på at ulikhetene på individuelt nivå var blitt betydelig redusert. Rundt 90 prosent av norske husholdninger har PC og Internett-tilgang, og andelen som har bredbånd, nærmer seg 80 prosent. Eldre, som er den gruppen som har hatt minst tilgang til digital teknologi, og som bruker den minst, er de som nå har den raskeste veksten i anvendelse av IKT. ${ }^{3}$ Dette betyr ikke at sosiale ulikheter i fysisk tilgang til IKT forsvinner, men at de etisk-politiske utfordringene i større grad handler om andre sider enn tilgang.

Dette gjenspeiles også i forskningen om digitale ulikheter som blant annet har vært opptatt av å utvide perspektivet fra å ha fokus på tilgjengelighet til også å se på bruk (Selwyn 2004; Gjedtjernet et al. 2007; Tsatsou 2011). For eksempel hevder van Dijk og Hacker (2003) at sosiale ulikheter når det gjelder kompetanse og bruk, antakelig er økende. Gurstein (2003) argumenterer for at digital ulikhet er mest interessant når det gjelder mulighetene for det han kaller effektiv bruk. Dette uttrykket knytter han til tilgangen på nyttige og brukbare anvendelser av IKT. Kommunale hjemmesider representerer potensielt sett en slik anvendelse.

Andre forskere tar forbehold om at debatten om digitale ulikheter gjenspeiler en teknologideterministisk tankegang gjennom den implisitte troen på at økt tilgang til IKT i seg selv er nyttig og kan bidra til å redusere sosial 
ulikhet (Gunkel 2003; Sassi 2005). Som påpekt blant annet av Wyatt et al. (2003), kan det være gode grunner til å velge ikke å bruke IKT. Da er det imidlertid viktig at valget er informert og ikke et produkt av for eksempel tilgjengelighetsproblemer. Generelt peker denne forskningen på at problemstillinger knyttet til digitale ulikheter må håndteres gjennom å balansere mellom å sikre mest mulig like muligheter og å avstå fra bruk av tvangsmidler for å øke anvendelsen av IKT.

Et sentralt poeng i denne sammenhengen er viktigheten av å ha fokus på inklusjon - på mekanismer som bidrar til bruk av IKT - og ikke bare på eksklusjon der digitale ulikheter framstår som produkt av hindringer for tilgang og bruk. I forlengelsen av Gursteins (2003) poeng om viktigheten av muligheter for effektiv bruk peker Sørensen et al. (under utgivelse) på hvordan anvendelse av PC og Internett motiveres av hva som kan oppnås. Dersom brukerne opplever at anvendelsen har nytteverdi eller underholdningsverdi, oppmuntres de også til å skaffe seg og videreutvikle den kompetansen som skal til for å oppnå de ønskede resultatene. I lys av dette har de kommunale hjemmesidene et potensial for å være en nyttig digital tjeneste, men også til å motivere innbyggerne til å lære seg å bruke slike tjenester. Det kan gjøre tilgangen til og kvaliteten av hjemmesidene dobbelt viktig.

På denne bakgrunnen vil vi hevde at det er viktig å utvide perspektivet bak forskningen om digitale ulikheter slik at det overskrider det tradisjonelle individfokuset med vekt på tilgang til nødvendig teknologi og kompetanse. Digitale ulikheter kan også handle om forskjeller i hva man faktisk gis mulighet til å gjøre ved bruk av for eksempel PC og Internett. Når vi er interessert i kommunale hjemmesider, aktualiserer det også et regionalt perspektiv. Vi vet at det er betydelige regionale forskjeller når det gjelder både tilgang til og bruk av IKT i Norge (Gjedtjernet et al. 2007). Disse forskjellene handler ikke nødvendigvis om befolkningstetthet. Schleife (2010) viser at en stor del av de regionale ulikhetene i IKT-bruk i Tyskland oppstår fordi det er forskjeller mellom urbane og rurale områder når det gjelder demografiske trekk, inklusive alder og utdanningsnivå. Likevel er befolkningstetthet viktig.

Når vi i denne artikkelen skal analysere norske kommuners hjemmesider, er det imidlertid en annen type geografisk dynamikk vi er opptatt av. Kommunene spiller en sentral rolle som leverandør av offentlige tjenester, $\mathrm{i}$ tillegg til at de representerer en lokal politisk arena. Slik sett er det tre hovedområder som berøres av de kommunale hjemmesidene, gitt at slike hjemmesider normalt vil være et redskap for å digitalisere kommunal virksomhet: (1) informasjon om og tilgjengeligheten av kommunale tjenester, (2) effektiviteten og kvaliteten av slike tjenester og (3) deltakelse i lokal politikk. Den IKT-politiske målsettingen er at digitalisering og satsning på hjemmesider skal bidra til forbedring på alle disse områdene (KS 2008). I vår sammenheng er det viktig at disse tre hovedområdene også gjelder for 
brukerne (innbyggerne). De skal kunne få bedre informasjon om og tilgang til kommunale tjenester på en mer effektiv måte, $i$ tillegg til å få en bedre og enklere tilgang til deltakelse i lokal politikk.

Samtidig er det slik - i tråd med etablerte norske prinsipper om lokalt selvstyre - at det er den enkelte kommune som har ansvaret for digitaliseringen og produksjonen av sin egen hjemmeside. Følgelig er det grunn til å forvente betydelige lokale variasjoner som like gjerne kan gjenspeile forskjellige kommunale prioriteringer som befolkningstetthet og andre demografiske forhold. I stedet for den «tradisjonelle» formen for digitale ulikheter som legger vekt på individuelle muligheter og ressurser, kan vi stå overfor geografisk betingede ulikheter som er avhengig av hvilken kommune man bor i. Det er faren for geografiske forskjeller i tilgangen på digitale kommunale tjenester som er utgangspunktet for denne artikkelen.

En slik form for digital ulikhet er spesielt interessant i et etisk-politisk perspektiv fordi den på en direkte måte er et produkt av politiske og administrative beslutninger i stat og kommune. Den er også interessant fordi den peker på en potensielt vanskelig etisk-politisk avveining mellom vekten på lokalt selvstyre - som kan produsere digitale ulikheter - og fokus på å motvirke digitale ulikheter - som kan forutsette inngrep i det lokale selvstyret.

Om slike avveininger faktisk skal betraktes som vanskelige, må vurderes i lys av konsekvensene av at kommunale hjemmesider har ulik kvalitet. På et generelt nivå innebærer konstruksjonen av en kommunal hjemmeside et forsøk på å standardisere samhandlingen mellom innbyggerne, administrasjonen og politikerne. Samtidig er denne standardiseringen ment å bedre kvaliteten på tilbudet, i første rekke når det gjelder hva hjemmesiden kan brukes til. Hva kan innbyggerne oppnå ved å klikke seg inn på sin kommunes hjemmeside?

Stevenson (2009) argumenterer for at debatten om digitale ulikheter i for stor grad har fokusert på individnivå der problemene forstås som knyttet til enkeltpersoners valg. Derfor er det viktig å forskyve oppmerksomheten mot tilbudssiden, slik vi gjør i denne artikkelen ved å være opptatt av kommunenes ulike tilbud når det gjelder digital tilgang på informasjon, tjenester og innflytelse. Antakelig er det stadig flere som benytter slike tjenester. Ifølge en Eurostat-survey hadde 68 prosent av befolkningen i Norge i 2010 benyttet seg av estat-tjenester i de siste tre månedene, mot 52 prosent i 2005. ${ }^{4}$ Andelen ikke-brukere er fortsatt ganske høy, og vi må anta at bruksfrekvensen blant dem som benytter seg av estat-tjenester, varierer betydelig. I hvor stor grad gjenspeiler dette forskjeller i det kommunale tilbudet, og hva er konsekvensene? Hvor store er de etisk-politiske utfordringene knyttet til utviklingen av kommunale hjemmesider? 


\section{Metode}

Artikkelen bygger på forskning med et eksplorerende siktemål. Hovedformålet har vært å få en oversikt over noen hovedtrekk ved ulikhetene mellom hva norske kommuner tilbyr gjennom sine hjemmesider, og drøfte hva slike ulikheter kan bety for innbyggerne. Vi har basert oss på tre hovedkilder:

1 Dokumenter som skisserer visjoner for digitalisering av norske kommuner, særlig eKommune 2012.

2 En kvantitativ registrering av hovedtrekk ved hjemmesidene til samtlige 430 norske kommuner. Denne registreringen ble gjennomført i juli/ august 2009 og fokuserte særlig på:

a. Tilbudet av informasjon og tjenester.

b. Mulighetene for kontakt med kommunale tjenestetilbud.

c. Mulighetene for kontakt med politikere.

d. Mulighetene for nettbaserte politiske diskusjoner.

e. Utbredelsen av Los, et forslag til informasjonsstandard for offentlige tjenester. ${ }^{5}$

3 En kvalitativ analyse av hjemmesidene til i alt ti kommuner: Bærum, Etne, Hamarøy, Leka, Marker, Modalen, Skien, Trondheim, Steinkjer og Vågå. Kommunene ble valgt ut for å gi variasjon når det gjaldt kvaliteten på og omfanget av det som var tilgjengelig gjennom hjemmesidene. Noen hjemmesider hadde et rikt innhold, andre var nokså enkle. Vi ønsket også variasjon når det gjaldt antall innbyggere, by/land og geografisk beliggenhet. Bærum og Trondheim er etter norske forhold relativt store byer, Skien og Steinkjer er forholdsvis små byer, mens Etne, Leka, Marker, Modalen og Våga alle er små rurale kommuner. Innholdet i hver enkelt hjemmeside ble analysert for å se på hvordan hjemmesiden organiserte informasjon, tjenester, konsultasjon og politisk deltakelse. Analysen ble gjennomført i løpet av sommeren og høsten 2010.

Materialet fra den kvantitative registreringen er analysert på en enkel måte. Vi har brukt regnearket Excel som har tjent som utgangspunkt for en kvantitativ kategorisering av kommuner i henhold til hoveddimensjonene som er nevnt ovenfor. Excel er også brukt til å sortere informasjonen for å gi et utgangspunkt for manuell telling. Vi har blant annet sortert etter innbyggerantall og urbanisering (bystatus eller ikke) for å vurdere effekten av disse egenskapene ved kommunene.

Den videre analysen er delt i to. Først drøfter vi funnene fra den kvantitative registreringen av norske kommuners hjemmesider. Deretter presenterer vi resultatene fra den kvalitative analysen av de utvalgte ti kommunale hjemmesidene med vekt på innholdet og forskjellene i innhold. 


\section{Fra visjon til virkelighet: store variasjoner}

Statistisk sentralbyrås undersøkelser av bruk av IKT i norske kommuner viser blant annet at de i økende grad bruker Internett (hjemmesider) som kanal for formidling av informasjon og tilbyr enkle interaktive tjenester som nedlasting og utskrift av skjemaer via nettet. Mer avanserte tjenester er lite utbredt, og det er klare forskjeller mellom store og små kommuner (Gjedtjernet et al. 2007: 113ff). Direktoratet for forvaltning og IKT (Difi) gjør årlige vurderinger av kvaliteten ved IKT-tilbudet i kommunene. Også de finner store forskjeller, men det er ikke bare store kommuner som topper listen. Faktisk er det en rekke forholdsvis små kommuner som scorer høyt og høyere enn store bykommuner. Bunnen av listen er imidlertid dominert av kommuner med forholdsvis få innbyggere. ${ }^{6}$

Både Difi og KS har engasjert seg i kommunal IKT-bruk gjennom plandokumenter, utvikling av standarder, rådgivning og informasjonsutveksling. Planene er ambisiøse. Som vi så innledningsvis, sier en i dokumentet «eKommune 2012 - lokal digital agenda» at norske kommuner og fylkeskommuner skal være blant de fremste i verden når det gjelder digitalisering (KS 2008: 6). Man skal oppnå bredere deltakelse i informasjonssamfunnet og bedre digital inkludering av innbyggerne, en mer helhetlig offentlig sektor, økt tjenestekvalitet, frigjøring av ressurser og mer effektiv intern drift. Det oppfattes også som viktig at kommunens bruk av IKT muliggjør både horisontal integrasjon med andre kommuner og vertikal integrasjon med nasjonale og regionale myndigheter og etater. Difi har også formulert visjoner om en mer samordnet nasjonal strategi som skal sikre «felles IKT-arkitektur i offentlig sektor», gjerne basert på en felles teknologisk infrastruktur. ${ }^{7}$ Det er ingen tvil om at de nasjonale aktørene ønsker seg størst mulig likhet i det kommunale IKT-baserte tilbudet, og dermed minst mulig av geografiske digitale skiller. Slik sett er de etisk-politiske målene om å unngå digital ulikhet på plass. Spørsmålet er om disse målene blir nådd.

Et eksempel på et tiltak for å nå de ovenfor nevnte målene er utarbeidelsen av Los, en felles informasjonsstandard for offentlige tjenester. Systemet er bygd opp av en liste med emneord som karakteriserer de vanligste offentlige tjenestene. Begrunnelsen for å bruke et slikt system gis ved følgende retoriske spørsmål: «Ville det ikke vært nyttig med et system som samlet all relevant informasjon om en offentlig tjeneste på ett sted, uavhengig av hvilke kilder den kommer fra? Det er det Los tar mål av seg til å tilby» (Norge.no 2007: 5).

Hva skal vi så forvente av kommunene? Statistisk sentralbyrå tegner et sammensatt bilde av den kommunale anvendelsen av IKT. For eksempel har 84 prosent av kommunene elektronisk saksstyring, mens bare 50 prosent har ikke-sensitiv informasjon digitalt tilgjengelig. Om lag halvparten av kommunene har en IKT-strategi som er oppdatert de siste to årene. ${ }^{8}$ Vi må åpenbart forvente at det er betydelig diskrepans mellom visjon og virkelig- 
het? Hva sier så vårt materiale om kommunale hjemmesider? Hva er det som tilbys, og hvor store er variasjonene?

Vi kan begynne med å notere at samtlige kommuner hadde hjemmeside pr. august 2009. Det eksisterer altså en form for estat-tilbud i alle norske kommuner. Hjemmesidene var imidlertid forskjellig utformet, og det skyldtes ikke bare grafiske variasjoner i layout og billedbruk. I så måte er det typisk at Los-standarden som skulle sikre lik presentasjon av informasjon, bare ble brukt av et lite mindretall. 68 kommuner (16 prosent) brukte denne standarden, 43 (10 prosent) brukte den delvis, mens 318 kommuner -74 prosent - ikke brukte Los-standarden i det hele tatt. Det er altså en lang vei å gå før kommune-Norge er samlet $\mathrm{i}$ et ensartet digitalt system, men dette er ikke nødvendigvis noe innbyggerne vil oppleve som et problem.

Hva så med kommuneadministrasjonens digitale tilgjengelighet? Vi fant at alle kommunene tilbød e-postkommunikasjon, men som regel var tilbudet meget enkelt. 393 kommuner - 91 prosent - kunne bare kontaktes ved hjelp av en felles e-postadresse for kommunen. En liten gruppe kommuner tilbød kontakt via chat eller sms, noen ganske få også interaktiv kontakt. Én kommune brukte det sosiale mediet twitter, og én hadde en digital spørretjeneste. Det overveldende flertallet av norske kommuner brukte altså ikke særlig avanserte tjenester for elektronisk kommunikasjon med innbyggerne. Dermed er det relativt høy grad av digital likhet på kommunikasjonsmessig tilgjengelighet.

Ut fra ekommune-idealene er det viktig med tilgang til kommunale tjenester via hjemmesidene. En målsetting var at nettstedene til norske kommuner skulle fungere som digital portal for bruk av kommunale tjenester, slik at kommunale tjenester kunne bestilles eller søkes om via nettet, og at forskjellige former for kommunale tillatelser som byggesaker kunne håndteres via hjemmesiden. Her viste det seg at de digitale ulikhetene var store. Det var bare et forholdsvis lite mindretall - 77 kommuner eller 18 prosent - som tilbød tilgang til kommunale tjenester i det vi vil regne som stort omfang. I 179 kommuner - 42 prosent - kunne innbyggerne ha tilgang til enkelte tjenester via hjemmesiden. De resterende 40 prosent av kommunene tilbød i beste fall nedlasting av skjemaer som så kunne sendes inn gjennom vanlig postgang. Innbyggerne i norske kommuner møtte altså en meget høy grad av digital ulikhet når det gjaldt tilgangen på tjenester via hjemmesidene.

Hva betyr dette? I første omgang kan det være interessant å se på hva slags tjenester som ble tilbudt. Den vanligste tjenesten var en interaktiv søknad om barnehageplass og svar på spørsmål om barnehagetilbudet i kommunen. Ellers var bildet temmelig variert. 18 prosent av kommunene tilbød som nevnt digital samhandling med alle eller nesten alle kommunale tjenester. De som tilbød et begrenset utvalg, hadde prioritert tjenester som skolefritidsordning, kulturtilbud, byggesaker og ledige stillinger. Denne 
typen tilbud er antakelig viktigst for aldersgruppen 25-45 år, som på denne måten får en forenklet kontaktmulighet - dersom de bor i de riktige kommunene.

Som vi har vært inne på tidligere, har potensialet for økt politisk deltakelse gjennom digitalisering av kommunene fått størst forskningsmessig oppmerksomhet. Tidligere forskning gir et nøkternt bilde av hva som er oppnådd (Baldersheim et al. 2008; Hansen \& Vabo 2008). Vi fant riktignok i vår undersøkelse at de fleste kommunene hadde hjemmesider som tilbød kontakt via e-post med lokale politikere. Bare 40 kommuner - 9 prosent hadde ikke noe slikt tilbud. I mange kommuner var det imidlertid bare ordføreren som kunne kontaktes, slik vi også så av undersøkelsen til Hansen og Vabo (2008). Pr. august 2009 gjaldt dette i 184 kommuner - 43 prosent. I 47 prosent av kommunene kunne politikere kontaktes via e-post. Vi fant videre at bare to kommuner tilbød chatting med ordføreren, mens det bare var i én kommune at ordføreren førte blogg. Tilbudet framstår ikke som spesielt imponerende, samtidig som vi finner markerte digitale ulikheter når det gjelder kontaktmuligheter.

Vi undersøkte også om det var etablert noen form for diskusjonsforum for kommunale spørsmål, siden dette forteller noe om utbredelsen av IKTløsninger for å skape et mer aktivt lokaldemokrati enn bare individuell kontakt med politikere. Det var, som forventet, få kommuner som tilbød innbyggerne slik digital politisk samhandling. 61 kommuner - 14 prosent hadde en eller annen form for diskusjonsfora, men i ti kommuner fungerte de ikke eller lå nede. Med utgangspunkt i studien til Hansen og Vabo (2008) er det dessuten grunn til å tro at aktiviteten i disse foraene er lav (jf. også Skogerbø \& Winsvold 2008). Det er selvsagt en digital ulikhet her også, men den er kanskje ikke så effektfull siden det ser ut til at digitale demokratiske praksiser i kommunene generelt sett er lite utviklet.

En skulle kanskje tro at det primært var de store kommunene som var gode på å bruke IKT til å formidle sine tjenester, og at de digitale ulikhetene fulgte et mønster der de samvarierte sterkt med antall innbyggere. Så enkelt var det imidlertid ikke. Tabell 1 viser sammenhengen mellom innbyggertall og forekomsten av noen typer av digitale tilbud. Hovedtendensen er riktignok at store kommuner tilbyr mer enn små, men bildet er ikke entydig. Ikke alle større kommuner hadde et godt tilbud, og noen små kommuner hadde innholdsrike hjemmesider. Tilgjengeligheten av digitale diskusjonsfora framstår som et interessant paradoks. Her var det faktisk de minste kommunene som hyppigst tilbød en slik mulighet. 
Tabell 1. Forekomsten av digitale tilbud via hjemmeside etter innbyggerantallet $i$ kommunen. Prosent. $(N=430)$

\begin{tabular}{|l|c|c|c|c|c|c|}
\hline \multicolumn{7}{|c|}{ Antall innbyggere } \\
\hline Type tjeneste & $\begin{array}{c}\text { Under } \\
\mathbf{2 0 0 0}\end{array}$ & $\begin{array}{c}\mathbf{2 0 0 0 -} \\
\mathbf{5 0 0 0}\end{array}$ & $\begin{array}{c}\mathbf{5 0 0 0}- \\
\mathbf{1 0 ~ 0 0 0}\end{array}$ & $\begin{array}{c}\mathbf{1 0 ~ 0 0 0 -} \\
\mathbf{2 0 ~ 0 0 0}\end{array}$ & $\begin{array}{c}\mathbf{2 0 ~ 0 0 0 -} \\
\mathbf{4 0 ~ 0 0 0}\end{array}$ & $\begin{array}{c}\text { Over } \\
\mathbf{4 0} 000\end{array}$ \\
\hline $\begin{array}{l}\text { Interaktive } \\
\text { tjenester }\end{array}$ & 36 & 48 & 76 & 78 & 85 & 100 \\
\hline $\begin{array}{l}\text { Kontakt med } \\
\text { politikere } \\
\text { (ikke bare } \\
\text { ordfører) }\end{array}$ & 34 & 41 & 59 & 60 & 70 & 61 \\
\hline $\begin{array}{l}\text { Digitalt dis- } \\
\text { kusjonsforum }\end{array}$ & 23 & 12 & 8 & 19 & 9 & 11 \\
\hline $\mathrm{N}$ & 97 & 136 & 88 & 58 & 33 & 18 \\
\hline
\end{tabular}

Tidligere forskning og statistikk fra SSB har pekt mot betydelige digitale ulikheter mellom norske kommuner. Vår studie bekrefter dette med vekt på hva som tilbys gjennom de kommunale hjemmesidene. Hva slags tilbud folk i Norge har gjennom sin kommunes hjemmeside, varierer etter bosted og påvirkes klart av størrelsen på den kommunen de bor i. De ambisiøse planene som foreligger om kommunal bruk av IKT, er langt fra innfridd, verken i retning av å sikre «eit informasjonssamfunn for alle» eller mot å oppnå en likeartet IKT-utvikling. Nesten 75 prosent av kommunene har valgt ikke å bruke forslaget til felles informasjonsstandard - Los. Det er en sterk indikasjon på at kommunene i stor grad ser på IKT-beslutninger som primært lokale, og i mindre grad som del av et nasjonalt prosjekt. Dermed er det stor sannsynlighet for at de betydelige digitale ulikhetene mellom kommunene vil bli opprettholdt $i$ årene framover.

Så langt vi har kartlagt det, dreier de digitale ulikhetene mellom kommunene seg framfor alt om hva slags tilbud innbyggerne får når det gjelder informasjon, kontaktmuligheter og elektroniske tjenester via den kommunale hjemmesiden. Hvordan arter slike forskjeller seg, og hva betyr de?

\section{Kommunale hjemmesider - hva slags utbytte?}

Hjemmesider er typiske sosiotekniske produkter der datateknologi, programmering, innhold og visuell utforming er forent på en sømløs måte. I den kvalitative analysen var vi primært interessert i hva slags tilbud kommunale hjemmesider kan utgjøre overfor innbyggerne i kommunen. Som nevnt var vi i første rekke interessert i å kartlegge i større detalj enn i den 
kvantitative undersøkelsen hva ulikheter i hjemmesidetilbudet til innbyggerne faktisk betød. Hva kunne innbyggerne i kommuner med innholdsrike hjemmesider oppnå, sammenliknet med kommuner med enklere og mer innholdsfattige hjemmesider? Slike spørsmål er viktige for å belyse hva de digitale ulikhetene vi observerte i forrige avsnitt, faktisk innebærer. De er også viktige som grunnlag for å vurdere alvorligheten i de etisk-politiske utfordringene som foreligger.

Steve Woolgar (1991) viser at en gjennom design av datateknologi utvikler forestillinger om hvordan framtidige brukere av teknologien «egentlig» er. Designet innebærer derfor et forsøk på å konfigurere brukerne, å utforme det Bruno Latour (1993) kaller et program som uttrykker hva designerne har tenkt om hvordan brukerne skal anvende teknologien. Vi har ikke studert selve designprosessen bak de kommunale hjemmesidene, men den kvalitative analysen pekte klart mot tre typer av brukerkonfigurasjoner eller brukerprogrammer:

- Den informasjonssøkende brukeren, dvs. en bruker som anvender hjemmesiden til å skaffe seg informasjon om forhold i kommunen.

- Den tjenestesøkende brukeren, dvs. en bruker som anvender hjemmesiden for å samhandle digitalt med tilgjengelige kommunale tjenester.

- Den politiske brukeren, dvs. en bruker som anvender hjemmesiden som grunnlag for digital kommunepolitisk deltakelse.

I prinsippet kan samme hjemmeside inneholde alle disse tre brukerkonfigurasjonene, men vi vet fra den kvantitative undersøkelsen at dette bare gjelder for et lite mindretall av norske kommuner. Det er dessuten betydelige ulikheter i hvor godt hjemmesidene legger til rette for hver av disse brukerkonfigurasjonene. Vi skal utdype dette i det følgende.

La oss starte med et eksempel på en innholdsrik hjemmeside. Bærum kommune ble i 2010 kåret av KS til landets beste eKommune for tredje gang på rad. Dette ble begrunnet med at de «har tatt i bruk elektroniske løsninger i kommunikasjonen med innbyggerne og er gode på tjenester på nett. Kommunen er langt fremme når det gjelder elektroniske tjenester innen helse og omsorg». ${ }^{9}$ Selve hjemmesiden inneholder bilder fra Bærum (alle de ti hjemmesidene har bilder fra egen kommune), i tillegg til en rekke knapper som gir brukeren anledning til å navigere seg fram gjennom forskjellige tema og tjenester. Slik fungerer hjemmesiden som en portal til en lang rekke former for informasjon, interaktiv tilgang til kommunale tjenester og kontakt/dialog med kommunen.

Med sine 110000 innbyggere er Bærum en forholdsvis stor kommune etter norske forhold, og den regnes også som ressursrik. Slik sett er det ingen overraskelse at kommunen var kommet langt med å gjøre informasjon og tjenester digitalt tilgjengelige. Brukere kunne søke om barnehage- 
plass interaktivt, men også mange andre saker kunne ordnes på tilsvarende måte, for eksempel kunne man søke om skjenkebevilling, bestille digitale kartdata, melde om hull i veier eller bestille tolketjenester. Informasjonsmengden som var tilgjengelig via hjemmesiden, var massiv. Det inkluderte mye informasjon om lokalpolitikken i Bærum, og hjemmesiden ga også muligheter til å kommunisere både med kommunen og lokalpolitikere, primært via e-post. Slik sett var det best tilrettelagt for informasjons- og tjenestesøking og i mindre grad for politisk deltakelse.

Hjemmesiden til Leka kommune sto i dramatisk kontrast til Bærums hjemmeside. Denne kontrasten illustrerer godt hva kommunebaserte digitale ulikheter kan dreie seg om. Tilbudet til de 588 innbyggerne i Leka kommune var meget lite og dreide seg i hovedsak om enkel informasjon på noen få saksområder. Ordføreren kunne kontaktes på e-post, men informasjonstilgangen var liten, og det fantes ingen interaktive tjenester.

Som vi har vært inne på tidligere, er det likevel en god del små kommuner som har mer omfattende tilbud. Etne kommune med 3898 innbyggere er en av dem. Her var hjemmesiden mer omfattende med flere typer av informasjon tilgjengelig, for eksempel om det meste av kommunens tjenestetilbud. Prislister var også inkludert. Hjemmesiden ga også informasjon om og til det lokale næringslivet og til besøkende, men Etne tilbød ikke interaktive tjenester.

I vår kvalitative analyse identifiserte vi tre hovedtyper av tilretteleggelse for den informasjonssøkende brukeren:

- Den omfangsrike hjemmesiden som ga et rikt tilbud av informasjon om en lang rekke sider ved kommunens virksomhet, men også om kulturtilbud o.l. Slike hjemmesider fant vi i Bærum, Hamarøy, Skien, Steinkjer og Trondheim.

- Oppslagstavle-hjemmesiden som i hovedsak var rettet inn mot å gi løpende informasjon om kommunale aktiviteter, i tillegg til informasjon om kommunen, lokalt næringsliv, lokalpolitikk og turisme. Slike hjemmesider fant vi i Etne, Marker, Modalen og Vågå.

- Nyhetsbrev-hjemmesiden der man primært valgte å formidle informasjon om kommunen og innbyggerne gjennom et nedlastbart, uformelt utformet nyhetsbrev som ble publisert om lag hver annen uke. En slik hjemmeside fant vi i Leka.

Når det gjaldt den tjenestesøkende brukeren, var ulikheten mellom hjemmesidene først og fremst et spørsmål om hvor mye som var tilgjengelig. Etne, Modalen og Vågå hadde ingen interaktive tilbud, mens Hamarøy og Marker bare hadde noen få. De interaktive tilbudene besto i hovedsak av lenker til nettbaserte skjema for å bestille tjenester, levere informasjon til kommunen eller søke om forskjellige typer av tillatelser. Det siste var 
primært rettet inn mot lokalt næringsliv. I de kommunene der hjemmesiden var best utbygd, var antallet slike skjema stort. For eksempel var i alt 121 skjema tilgjengelige fra Bærum kommunes hjemmeside.

Den politiske brukeren så ikke ut til å være viktig for de undersøkte kommunene. Hjemmesiden til Trondheim kommune tilbød for eksempel en massiv mengde informasjon om lokalpolitikken, inkludert nedlastbare sakspapirer og referater. Men under punktet «kanaler for dialog» ble man informert om at «[b]este måte for å nå politikere i Trondheim bystyre, er å sende en e-post». Bare Skien tilbød noe mer. Her inneholdt hjemmesiden en mulighet til å chatte med ordfører eller varaordfører på bestemte tidspunkter, og det var en lenke til webkameraoverføring fra bystyremøtene.

\section{Geografiske digitale ulikheter - og hva så?}

På bakgrunn av tidligere forskning var det kanskje ikke så overraskende at vi fant til dels store forskjeller mellom norske kommuner når det gjaldt det digitale tilbudet til innbyggerne gjennom de kommunale hjemmesidene. Disse ulikhetene handlet om omfanget av og kvaliteten ved det digitale tilbudet av både informasjon og kommunale tjenester. Det var også forskjeller i mulighetene for nettbasert lokalpolitisk engasjement, men det var primært knyttet til tilgang på lokalpolitisk informasjon. Hvor viktig var de etiskpolitiske utfordringene som følge av disse observasjonene?

Som et utgangspunkt vil vi understreke at sammenliknet med tradisjonelle studier av digital ulikhet representerer vår undersøkelse en annerledes tilnærming. I stedet for et fokus på individuelle brukeres tilgang på IKT i form av utstyr - PC, Internett, bredbånd - har vi rettet oppmerksomheten mot geografisk betingede ulikheter i tilbudet av digital informasjon og digitale tjenester. Dette representerer også en etisk-politisk perspektivendring. Når blikket rettes mot ulikheter i tilbudet, blir det tradisjonelle politiske fokuset på å bedre enkeltbrukeres tilgang til IKT mindre relevant. I stedet ser vi at en politikk for større digital likhet må rettes inn mot mulighetene for «effektiv bruk» (Gurstein 2003) gjennom å sikre at tilbudet av for eksempel nettbasert kommunal informasjon og tilgangen på interaktive tjenester blir likere.

Som vi var inne på tidligere, møter imidlertid sentrale myndigheter et politisk-etisk dilemma i håndteringen av ulikhetene i det kommunale digitale tilbudet. Antakelig krever det sterkere sentral styring dersom ulikhetene skal reduseres. Samtidig bryter sterkere sentral styring med en sentral politisk verdi i Norge - det lokale selvstyret. Følgelig blir det viktig å vurdere hvor betydningsfulle disse digitale ulikhetene er. Er de viktige nok til å redusere det kommunale selvstyret når det gjelder bruk av IKT? 
Vi har ikke undersøkt hvor stor vekt innbyggerne legger på det digitale tilbudet gjennom kommunenes hjemmesider, og hvordan de vurderer ulempene med et dårlig tilbud. Teoretisk sett er likevel fordelene ved godt utbygde hjemmesider opplagte. Slike hjemmesider bidrar til at innbyggerne blir mindre avhengige av telefonisk eller fysisk kontakt med kommunalt ansatte, og dermed av åpningstider og fysisk frammøte. Digitalt tilgjengelige tjenester er antakelig tidsbesparende og skaper større fleksibilitet gjennom større frihet i valget om hvor og når samhandling skal foregå. I en norsk survey-undersøkelse om holdninger til offentlige tjenester på Internett sier da også 61 prosent at de foretrekker å sende søknader til stat eller kommune elektronisk. ${ }^{10}$ En godt utbygd hjemmeside innebærer dessuten at det blir enklere å skaffe seg oversikt over kommuneadministrasjonen og organiseringen av det kommunale tjenestetilbudet. Slik sett innebærer digitalisering at kommunene i prinsippet blir mer gjennomsiktige for brukerne. Mye tyder derfor på at gode kommunale hjemmesider gjør hverdagen enklere for innbyggerne, og at det derfor er viktig å sikre større grad av digital likhet.

Samtidig er det noen forhold som kan virke modifiserende på dette positive bildet av et digitalt informasjons- og tjenestetilbud gjennom kommunale hjemmesider. For det første kan det tenkes at de kommunale hjemmesidene egentlig er et sidespor i utbyggingen av Norge som informasjonssamfunn. Innbyggere i Norge har gjennom den statlige ordningen med Minside, etablert av Fornyings-, administrasjons- og kirkedepartementet, tilgang til en individualisert nettside som inkluderer forbindelser til hjemkommunens digitale tjenester, i tillegg til tjenester som utføres av fylkeskommune og stat. Det kan i hvert fall argumenteres for at Minside-ordningen overflødiggjør kommunale hjemmesider og deres tilbud av interaktive muligheter. Informasjonstilfanget overlapper vesentlig, men Minside mangler det lokalkulturelle preget som de kommunale hjemmesidene har, inkludert den spesifikke informasjonen om lokale aktiviteter og hendelser. Minside reduserer heller ikke de digitale ulikhetene. Fortsatt er tilgangen på kommunale digitale tjenester avhengig av hvor du bor, og hva din hjemkommune tilbyr. Den lokale tilhørigheten blir imidlertid mindre tydelig i den digitale representasjonen av den enkelte norske samfunnsborger gjennom Minside.

For det andre kan en satsning på kommunale hjemmesider være et sidespor fordi de bryter med de vanlige strategiene folk flest anvender når de bruker nettet. Som Dutton og Eynon (2009) peker på, bruker folk flest søkemotorer av typen Google for å finne informasjon på nettet. Kommunale hjemmesider kan i så måte bli en dinosaur. Store deler av den informasjonen som vi kan finne på for eksempel hjemmesiden til Bærum kommune, dreier seg om nasjonale forskrifter og prosedyrer og er i prinsippet felles for alle kommuner. Det som er spesifikt, er opplysninger om rent lokale for- 
hold. Kanskje representerer de antatt beste kommunale hjemmesidene en slags informasjonsmessig overkill?

Vi fant i vår undersøkelse en klar, men ikke helt entydig tendens til at små kommuner hadde et dårligere digitalt tilbud enn store. Dette kan virke paradoksalt når vi vet at innbyggerne i små kommuner gjennomgående er mer tilfredse med kommunale tjenester enn innbyggerne i store kommuner (Monkerud \& Sørensen 2010). Det kan imidlertid tenkes at innbyggere i små kommuner har mindre behov for en hjemmeside med mye informasjon og digitaliserte tjenestetilbud, enn de som bor i store enheter. Det kan også være at en større grad av personlig kjennskap til de som arbeider i kommunen, gjør det mindre interessant med frihet i tid og rom når det gjelder kontakt med kommunale tjenester. Samtidig finner Monkerud og Sørensen (2010) at innbyggerne i små kommuner er mer tilfredse med kommunale tjenester, ikke så mye på grunn av størrelsen som en effekt av utdanningsnivå, alderssammensetning og nivået på kommunens inntekter. Små kommuner kan også ha store geografiske avstander som gjør elektronisk tilgang på informasjon og tjenester klart tidsbesparende.

Det kreves mer kunnskap om betydningen av geografiske digitale ulikheter, men vi har grunn til å tro at slike ulikheter har uønskede effekter og en høyst reell betydning for livskvaliteten. Derfor er de digitale ulikhetene mellom norske kommuner ikke bare forskningsmessig interessante, men også urovekkende. Mosco (2004) minner om at en av visjonene bak utviklingen av IKT har vært at betydningen av geografi ville bli opphevd, at datateknologi og Internett ville gjøre det betydningsløst hvor man bodde. Vår undersøkelse viser at når vi interesserer oss for de digitale tilbudene fra norske kommuner, ser vi at visjonene ikke er oppfylt. Geografi er igjen (eller fortsatt) viktig fordi det er lokale variasjoner i kvaliteten på det digitale tilbudet, som altså ikke handler om bredbånd og maskinvare.

I et samfunn som legger stor vekt på regional likhet og den regionale dimensjonen i politikken, representerer geografiske digitale ulikheter en åpenbar etisk-politisk utfordring. Det er imidlertid ikke opplagt hvordan den bør håndteres. Denne artikkelen er ment som et bidrag til å motivere for en videre innsats gjennom å synliggjøre problemet. I tillegg har vi ønsket å vise fruktbarheten av å endre fokuset på etisk-politiske utfordringer knyttet til digital ulikhet: Fra å være opptatt av individuell tilgang til teknologi, må en konsentrere seg mer om kollektivt produserte tilbud av tjenester.

I et større perspektiv kan man kan selvsagt se for seg en meny av mulige tiltak mot de observerte forskjellene som inkluderer større bevilgninger, økt sentral innsats og kompetanseoppbygging i kommunene. Antakelig forklarer ulik tilgang på ressurser en god del av ulikhetene i tilbudet gjennom de kommunale hjemmesidene. Det er imidlertid små og relativt ressursfattige kommuner som har et forholdsvis godt digitalt tilbud. Det tyder på at det også er tale om at kommunene følger forskjellige strategier for digitalise- 
ring. I den sammenheng kan det tenkes at en del kommuner er for opptatt av økonomiske og administrative aspekter, og at de derigjennom overser den typen etisk-politiske utfordringer som denne artikkelen har bidratt til å identifisere.

\section{Takk}

Arbeidet med denne artikkelen har vært støttet av Norges Forskningsråd, Verdikt-programmet. Takk til Eirik Swensen for assistanse med datainnsamling. Takk også til redaktørene av Etikk i praksis for nyttige kommentarer.

\section{Noter}

1 St.meld. nr. 17 (2006-2007) Eit informasjonssamfunn for alle, s. 22.

2 Jf. Innst. S. nr. 158 (2006-2007) Innstilling fra transport- og kommunikasjonskomiteen om eit informasjonsamfunn for alle og Stortinget - Møte mandag den 16. april $2007 \mathrm{kl}$. 12, sak $n$ r. 3.

3 www.ssb.no/ikthus (lastet ned 2010-07-08).

4 http://appso.eurostat.ec.europa.eu/nui/print.do?print=true (lastet ned 2011-05-30, ikke lenger tilgjengelig).

5 Norge.no: Håndbok for innføring av Los - en informasjonsstandard for offentlige tjenester, www.norge.no (lastet ned 2010-07-06).

6 http://kvalitet.difi.no/resultat/?aar=2010\&verksemdtype=9\&stjerner=0\&fyl$\mathrm{ke}=1$ \&sortering $=5$ (lastet ned 2011-06-06).

7 Jf. notatet «Omstilling til ny IKT-infrastruktur i offentlig sektor», utarbeidet av Kåre Fløisand og Åge Borg-Andersen, datert 2009-09-09.

8 http://ssb.no/iktbrukk/ (lastet ned 2010-07-08).

9 http://www.ks.no/tema/Innovasjon-og-forskning/Teknologi-og-IKT/Hat-trick-tilBarum-Vinner-eKommune-prisen-for-tredje-gang/ (lastet ned 2010-07-08, ikke lenger tilgjengelig).

$10 \mathrm{http} / /$ www.difi.no/filearchive/holdninger-til-digitale-tjenester-og-elektroniskid_1.pdf (s. 15) (lastet ned 2011-06-09).

\section{Litteratur}

Dutton, W.H. \& Eynon, R. (2009) Networked Individuals and Institutions: A Cross-Sector Comparative Perspective on Patterns and Strategies in Government and Research. Information Society 25 (3), s. 198-207.

Flak, L.S., Olsen, D.H. \& Wolcott, P. (2005) Local E-Government in Norway. Current Status and Emerging Issues. Scandinavian Journal of Information Systems, 17 (2), s. 41-84.

Frønes, I. (2002) Digitale skiller. Utfordringer og strategier, Bergen: Fagbokforlaget. 
Gjerdtjernet, P.E., Kalvøy, A, Kordahl, O.-P., Lorentzen, K. \& Pilskog, G.M. (2007) Nøkkeltall om informasjonssamfunnet 2006. Oslo: SSB.

Gunkel, D.J. (2003) Second thoughts: toward a critique of the digital divide. New Media \& Society, 5 (4), s. 499-522.

Gurstein, M. (2003) Effective use: A community informatics strategy beyond the Digital Divide. First Monday, 8 (12) (Tilgjengelig fra http://www.uic.edu/htbin/ cgiwrap/bin/ojs/index.php/fm/article/view/1107/1027)

Hansen, G.S. \& Vabo, S.I. (2008) Styringsdilemmaer i lokaldemokratiet - økte utfordringer med digitalisering? I Digitale dilemmaer. Nye medieformer, nye utfordringer, red. G. Enli og E. Skogerbø, s. 18-38. Oslo: Gyldendal akademisk.

Haug, A.V. (2008) Internett som kanal for politisk kommunikasjon: Hvordan kan det gjøres? Hvem er foregangskommunene? I Mot den virtuelle kommunen. Studier i e-demokrati og e-forvaltning, red. H. Baldersheim, A.V. Haug \& M. Øgård, s. 77-119. Bergen: Fagbokforlaget.

Heeks, R. \& Bailur, S. (2007) Analyzing e-government research: Perspective, philosophies, theories, methods, and practice. Government information quarterly, 24 (2), s. 243-265.

Jensen, M.J., Danziger, J.N. \& Venkatesh, A. (2007) Civil society and cyber society: The role of the internet in community associations and democratic politics. Information Society 23 (1), s. 39-50.

KS (2008) eKommune 2012 - en lokal digital agenda. Oslo.

Latour, B. (1993) Where Are the Missing Masses? The Sociology of a Few Mundane Artifacts. I Shaping Technology/Building Society. Studies in Sociotechnical Change, red. W.E. Bijker, \& J. Law, s. 225-258. Cambridge, MA: The MIT Press.

Liste Muñoz, L. (2010) Exploring E-Government. Upublisert arbeidsnotat. Trondheim: NTNU, Institutt for tverrfaglige kulturstudier.

Lusoli, W., Ward, S. \& Gibson, R. (2006) (Re)connecting Politics? Parliament, the Public and the Internet. Parliamentary Affairs, 59 (1), s. 24-42.

Monkerud, L.C. \& Sørensen, R.J. (2010) Smått og godt? Kommunestørrelse, ressurser og tilfredshet med det kommunale tjenestetilbudet. Norsk Statsvitenskapelig Tidsskrift, 26 (4), s. 265-295.

Mosco, V. (2004) The Digital Sublime. Myth, Power and Cyberspace, Cambridge, MA: The MIT Press.

Norge.no (2007) Håndbok for innføring av Los - en informasjonsstandard for offentlige tjenester.

Norris, D. \& Lloyd, B. (2006) The Scholarly Literature on E-Government: Characterizing a nascent field. International Journal of Electronic Government Research 2 (4), s. 40-96.

Norris, P. (2001) Digital Divide. Civic engagement, Information Poverty, and the Internet Worldwide. Cambridge: Cambridge University Press.

Peristeras, V., Mentzas, G., Tarabanis, K. A. \& Abecker, A. (2009) Tranforming Egovernment and E-participation through IT. IEEE Intelligent Systems, September/October, s. 14-19.

Saglie, J. \& Vabo, S.I. (2009) Size and e-Democracy: Online Participation in Norwegian Local Politics. Scandinavian Political Studies, 32 (4), s. 382-401.

Sassi, S. (2005) Cultural differentiation or social segregation? Four approaches to the digital divide. New Media \& Society, 7 (5), s. 684-700.

Schleife, K. (2010) What really matters: Regional versus individual determinants of the digital divide in Germany. Research Policy, 39, s. 173-185. 
Selwyn, N. (2004) Reconsidering political and popular understandings of the digital divide. New Media \& Society, 6 (3), s. 341-362.

Skogerbø, E. \& Winsvold, M. (2008) Nettet som debattarena. I Digitale dilemmaer. Nye medieformer, nye utfordringer, red. G. Enli, \& E. Skogerbø, s. 39-60. Oslo: Gyldendal akademisk.

Stevenson, S. (2009) Digital Divide: A Discursive Move Away from the Real Inequalities. The Information Society, 25, s. 1-22.

Sørensen, K.H., Faulkner, W. \& Rommes, E. (under utgivelse) Technologies of Inclusion: Gender in the Information Society. Trondheim: Tapir Akademisk Forlag.

Tsagarousanou, R., Tambini, D. \& Bryan, C. (red.) (1998) Cyberdemocracy. Technologies, cities and civic networks. London: Routledge.

Tsatsou, P. (2011) Digital divides revisited: what is new about divides and their research? Media, Culture \& Society, 33 (2): 317-331.

van Dijk, J. \& Hacker, K. (2003) The Digital Divide as a Complex and Dynamic Phenomenon. The Information Society, 19, s. 315-326.

West, D.M. (2004) E-Government and the Transformation of Service Delivery and Citizen Attitudes. Public Administration Review, 64 (1), s. 15-27.

Wiklund, H. (2005) A Habermasian analysis of the deliberative democratic potential of ICT-enabled services in Swedish municipalities. New Media \& Society, 7 (2), s. 247-270.

Woolgar, S. (1991) Configuring the User: the case of usability trials. I A Sociology of Monsters, red. J. Law, s. 57-102. Sociological Review Monographs 38. London: Routledge.

Wyatt, S., Thomas, G. \& Terranova, T. (2003) They Came, They Surfed, They Went Back to the Beach: Conceptualizing Use and Non-Use of the Internet. I Virtual Society? Get Real! Technology, Cyberbole, Reality, red. S. Woolgar, s. 23-41. Oxford: Oxford University Press. 